\title{
御茶屋絵図から見た福岡藩御茶屋の空間・意匠構成 福岡藩御茶屋に関する研究 (1) \\ THE SPATIAL COMPOSITION AND DESIGN OF O-CHAYA IN FUKUOKA DOMAIN BASED ON DRAWINGS \\ A study on the o-chaya in Fukuoka domain Part 1
}

安高尚毅*, 宮本 雅明**

Naoki ATAKA and Masaaki MIYAMOTO

\begin{abstract}
The purpose of this study is to clarify architectural feature of o-chaya in Fukuoka domain. This study is based on Utino,Akama,Yamae's drawings. This study gives attention to the outer building and the inner building and design. As a result, site plan and building plan have many points in common. Three $o$-chaya divide into four parts in terms of space and design. O-genkan part is traffic place whose design is syoin. O-hiroma part is meeting place whose design is informal syoin. O-ima part is resting place whose design is like sukiya. Tumesyo-daidokoro part is cooking and administration place whose design is like minka.
\end{abstract}

Keywords : O-chaya,Fukuoka domain,Utino,Akama,Yamae

御茶屋、福岡藩、内野、赤間、山家

序

近世の御茶屋と呼ばれたものには様々な用途、規模、形式のものが 存在した。御茶屋を建設した者も宮家、公家、武家と多様な階級に亘っ ていた。文献史料に見られる御茶屋の語も本陣や町茶屋の意味に使用 されるなど、その解釈は諸書で混乱が見られる。川上貢氏は、御茶屋 は「ある特定の人の専用施設として庭間の散策または旅行などの道程 の中途に位置して、飲食、休息または宿泊に充てるためのもの」と概 括されると言う注1)。この様に広範に及ぶ御茶屋の意味の中で、本稿 の御茶屋は将軍の上洛、遠征、大名の参勤交代、領内巡見の休鄎・休 泊施設として設けられた武家の御茶屋を指す。

これまで武家の休泊に使用された御茶屋の研究は交通史・歴史地理・ 建築史の立場から研究されている。

交通史では丸山雍成氏が近世宿駅に関する宿・本陣・御茶屋の関係 性と、歴史的変遷を考察している注 2)。丸山氏は御茶屋が領主的交通 の休泊機能を遂行し、江戸中期以降五街道では御殿御茶屋は消滅し、 御茶屋が本陣にその機能を移行・転化し、脇街道では御茶屋と本陣の 両性格を併有したという。

一方、歴史地理では中島義一氏が将軍の御殿御茶屋に着目し、御殿 御茶屋が大名の宿泊を許さず、将軍自身は本陣を利用しておらず、そ れらの用途は異にして併存したとする注3)。

丸山氏は武家の休泊施設が藩営から民営へ移行したことに重点を置 き、中島氏は使用者の違いから用途が別になることに重点を㯰くこと
から、これらの説の違いは研究分野によるものと考えられる。

交通史・歴史地理の先行研究に共通することは御茶屋を単なる休泊 施設として捉えている点である。御茶屋と本陣が異なる目的で建設さ れたのであれば、単なる休泊施設として捉えるのではなく、その奥に ある意味が重要であろう。また、御茶屋と本陣の定義も空間に裏付け されること、つまり建築史的な検討が必要であると考える。

建策史の先行研究は、川上貢、岡田悟氏の研究が代表される注4)。 川上氏は将軍家が設けた永原御茶屋について、平面構成を中心に検討 している注5)。岡田氏は萩藩注 6) と庄内藩注 7$)$ の複数の御茶屋について 主に平面構成を検討しながら、使用状況も検討している。

岡田氏は萩藩の御茶屋は潘主が国迴り時に御茶屋に宿泊したこと、 平面の基本構成要素を番所部分・御座間部分・台所部分の 3 つする こと、勘場と呼ばれる役所が、御茶屋の敷地に隣接して設けられてい る所があることを明らかにし、生内藩では藩主が御茶屋に、他藩藩主 は本陣に宿泊し、平面の基本構成要素を番所広間部分・御居間部分・ 台所部分の 3 つをすることを明らかにしている。

建築史においてはそれぞれ詳細な分析を行っているが、室名と間取 りしかわからないという史料的制約から空間・意匠構成に関してはそ れほど深く検討されていない。また岡田氏は萩藩、生内藩を集中して 取り扱い、藩全体の御茶屋の状況を把握することが重要であるとしつ つも、現段階では御茶屋を個別に研究するに留まり、総体的に萩藩・ 厷内藩の御茶屋像を結んでいないように思われる。平面の区分も室名

本稿は，『日本建築学会九州支部研究報告集(計画系)』(2005年)に発表した内容をもとに加筆・修正したものである。

* 東和大学環境デザイン工学科 講師・芸工修 Lecturer, Tohwa University, M. Design

** 九州大学大学院芸術工学研究院 教授・工博 
から機能を類推し区分しており、必ずしも厳密な区分とは言えない。 区分は外部空間を対象としておらず、後述するように内外部を一体的 に捉えることが重要である。また御茶屋という建築形式は全国共通な のか、または藩によって特徴があるのかという問題も考えられ、より 一層の研究の樑化が求められる。

ところで、福岡藩にはこの様な諸問題に答えうる史料が残される。 残される史料の中でも文化八年（1811）の「内野御茶屋絵図」注8)、 天保五年（1834）の「赤間御茶屋御家通図」注9)、「御茶屋々々御家坪 数其外口々書留义在役衆役宅坪数共」(「御茶屋書留」と呼ぶ）注 10) が 特に重要である。

「内野御茶屋絵図」「赤間御茶屋御家通図」は外構と建築の全体を極 めて詳細に描き、建築物や工作物の仕棣まで記述しており、部屋名、 建具の種類、床仕上、天井仕上、壁仕上、屋根仕上が知られる。これ により内部と外部との空間の関連性と空間構成が把握でき、意匠構成 も検討できる。平面だけでない外部空間を含めた検討および意匠の検 討は御茶屋という空間をより染く追究でき、御茶屋という建築形式の 本質により迫ることができると考えられる。

「御茶屋書留」は御茶屋・町茶屋の主屋・付属屋等の規模、材質、 塀長さ、垣長さ、屋根形式を知ることができるほか、代官御茶屋役宅 とその他役宅の主屋・付属屋等の規模・材質を知ることができる。こ れにより藩全体を通した御茶屋の建築構成を捉えることが可能とな る。

一方、福岡藩における御茶屋の研究は文献史学から近藤典二氏が、 福岡藩の御茶屋・町茶屋に関連する史料をまとめ、歴史学の立場から その管理・使用状況について検討している住11)。建築史学からは太田 静六氏が民家研究の中で、山家及び三奈木の御茶屋を取り上げ紹介し ているが注 12)、福岡藩の御茶屋の建築的特徵を体系だてて捉えている わけではない。この様な中で、福岡藩の御茶屋は用途は遊興に使用さ れ、私的に活用されたものと、休泊に使用され、公的に活用されたも のに大別でき、所有者潘主と家臣に大別される。これらの中で福岡 藩では圧倒的に藩主の公的に活用された御茶屋が多数を占めることか ら、本研究は公的に活用された御茶屋を中心に展開する。

よって、本研究は先行研究において史料的制約のため未だ解明され ていなかった御茶屋の外部空間と内部空間の関連性および意匠構成を 把握すること、御茶屋を個別に把握するのではなく、福岡藩という枠 組みの中で建築的特徵を明らかにすること、藩に於ける御茶屋という 存在を系統だてて捉えること、広範に及ぶ御茶屋の意味の一端を押さ えつつ、福岡藩に於ける御茶屋の成立と展開を把握することを目的と する。そして最後に御茶屋という建築類型が何故生まれ、または何故 つくられたのかという問題の解決に筋道を付けたい。

本研究の流れを以下に示す。まず平面絵図を基に内野・赤間・山家 御茶屋の空間構成を比較検討し、意匠の詳細の把握される絵図を基 に内野·赤間の意匠構成を比較検討し、それらを照合し、建築的特徵 を捉える。次に福岡藩御茶屋の分布状況を把握しつつ、「御茶屋書留」 を基に福岡藩に散在するすべての御茶屋の建築構成、文政 5 年という 一断面の状況を把握する。さらに福岡藩御茶屋に関する史料をまとめ 年表を作成し、使用頻度と使用状況を把握しつつ、成立と展開過程を 把握する。最後に以上の結果をまとめ、御茶屋が何故つくられたのか という問題の実相に迫りたい。

このうち本稿では福岡藩御茶屋がどのような空間・意匠構成を備え
ていたのかを平面絵図を通して検討する。

\section{1. 福岡藩御茶屋の絵図史料}

前述の絵図史料のほか、空間構成が把握できる絵図に享和元年 (1801) の「山家駅御茶屋図」(「山家享和図」と呼ぶ) 注 13)、文久二年 $(1862)$ の「御出会達御間取絵図御笠郡山家御茶屋/図」(「山家文久図」と呼ぶ) 注 14)、年代不祥の「山家御茶屋二付奉行出会之節」(「山家奉行出会図」 と呼ぶ）注 15)、「御茶屋野取図」注16) がある。これらが基本史料となり 内野・赤間・山家御茶屋の検討が可能となる。

これらの絵図は、時代の近い史料である「御茶屋畵留」の記述内容 と建築内容が一致することから、その内容にも信が怙ける注 17)。間取 りが部分的にしか描かれない「山家奉行出会図」も、他の山家御茶屋 を描く絵図と描かれる部分がほぼ一致し、信恣性は高い。

「内野御茶屋絵図」「赤間御茶屋御家通図」は表現手法が同じで、凡 例はないものの、「御茶屋書留」と照合することによって、絵図に記 された文言、描かれた図面と色分けからそれらを把握することができ

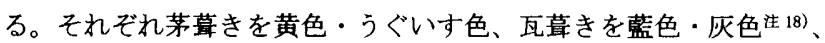
建具を赤色の点線と実線で表現し、それぞれ空と掃き出しの建具を意 味していることが知られる主 19)。内野はこれ以外の色も使用し、灰色 は石を、緑色は植栽、水色は池、無色の縁は上部に屋根を設けないこ とを表していることが知られる。絵図に書かれた文言とこれらにより 内野・赤間御茶屋は空間構成および意匠構成の分析が可能となる

「山家享和図」は主屋と附属屋の平面形式、部屋名、建具の種類、 一部の外構が知られ、付篦からは使用時の人員配置々所作が知られる。 建具捇色の点線と実線で表現し、それぞれ空と掃き出しの建具を意 味する。「山家文久図」は主屋の平面形式、部屋名、出会時の人員配 置および仮設間仕切りの配置が知られ、色分けから黄色が冨、灰色が 板敷き、緑色が下屋を表していると考えられる注21)。両者は 61 年の開 きから平面の一部に違いが見られるものの、主要な部屋に变化はない。 これら二葉の絵図は内野・赤間に比して各部仕上が書かれず、配置も 敷地周囲が全て描かれないなど知られる情報に劣る。「山家奉行出会 図」は前述のように平面の一部を描くものであるが注22)、「山家享和図」 に描かれない東側の垣と塀の存在が知られる。また、山家御茶屋の敷 地を描く「御茶屋野取図」からは、池のおおまかな位置と生垣の様相 が知られる。

以上の検討結果と絵図を基に、外構を含んだ読取平面図を作成した (図 1.2.3) 注23)。

\section{2. 福岡藩御茶屋の外部空間構成}

御茶屋の敷地は内野・山家は周囲を練塀と生垣で囲い、赤間はこれ らに加えて矢来も用い、これら囲繞装置の外側を赤間は薮で囲い、山 家は南側道路を介して下代屋敷を 4 軒並心゙、西側に水路を通すなど、 閉鎖的な構えを呈していた。

教地の中は完全に復原できる内野・赤間は塀や垣によっていくつか の空間に区切られる。完全に復原できない山家もこの傾向が窺える。 各御茶屋とも敷地中央に主屋を構え、主屋中央に中庭を取ることは共 通する。

塀や垣により囲われた空間を最も明確に区分するのが内野御茶屋 で、塀や垣により囲われる主屋に面した空間と、塀や垣により囲われ る主屋に面しない空間に大別される。前者は A・B・C・D の四ゾーンに、 
後者は $\mathrm{a} \cdot \mathrm{b}$ のニゾーンに分けられる。明快に分け られる内野の A・B・C・D を平面と照合すると、主 要な諸室に面しているのに気付く。Aが「御式台」、 $\mathrm{B}$ が「上ノ間小、Cが「御居間」、Dが「上・下臺所」 に面する。これを基本とし、赤間も区分すると $\mathrm{A} \cdot \mathrm{B}$ ・ $\mathrm{B}^{\prime} \cdot \mathrm{C} \cdot \mathrm{C}^{\prime} \cdot \mathrm{C}^{\prime}{ }^{\prime} \cdot \mathrm{D}$ の七ゾーンにわけられる。図 より $\mathrm{B}^{\prime} \cdot \mathrm{C}^{\prime} \cdot \mathrm{C}^{\prime} ’$ は $\mathrm{B} \cdot \mathrm{C}$ に付属した空間と捉える ことができよう。山家は外構を完全に復すること が出来なかったが、緩やかに外部空間が分けられ ることと、内野・赤間が区分されることに習い、A・B・ $C \cdot C^{\prime} \cdot D \cdot D^{\prime} \cdot D^{\prime \prime}$ の七ゾーンに分けた。なお赤間・ 山家は主屋に面しない囲われた空閒はない。

Aゾーンはともに表門を潜ったところに広がる 練塀で囲まれた空間で、表御門脇に番所を従え、

腰掛・御駕籠部屋を配する。内野は東に繴、中央 に雁木・銀杏の木を設ける。

BゾーンはAゾーンから中門・路次を潜った塀 と垣で囲まれた空間である。内野は bゾーンを介 する。山家はここに池を配する。赤間の B'ゾーン はBゾーンから路次を潜って入った広場である。

CゾーンはBゾーンに隣接する垣と塀で囲まれ た空間である。内野はbゾーンを介する。C’ゾー ンは赤間は練塀と駕籠塀で囲まれた主屋の「御湯 殿」等が面する空間で、山家は「御寝所」等に面 する練塀で囲われた空間である。赤間のC' ゾー ンは主屋の「御居閒」の南側、鴐籠塀と板塀で囲 まれた空間である。

Dゾーンは練塀と垣で囲まれた広大な空間で、 出入りが可能な場所に番所を設け、池を配する。 内野と赤間は小屋・下雪鿵を配し、内野と山家は御道具蔵が配 される。山家は井戸を 2 筒所配し、外慗・御廐それに付属し、 番所を配する。内野は a ゾーンとの境に桝形と番所を設ける。 赤間は表御門東に御台所門を設け、敷地東端に隱抜溝を配する。 内野はこの空間を生垣・竹垣により緩やかに 3 つに区分する。 これらをD1, D2, D3 ゾーンと呼ぶ。山家の D’ ゾーンは Dゾーン から路次を潜った主屋の台所等に面した練塀で囲まれた空間で、 D' ゾーンは次惣詰に面した練塀で囲まれた空閒である。

以上、福岡藩御茶屋は閉鎖的な構えを呈し、敷地の中はいく つかの空間に分けられていた。Aゾーンは腰掛や駕籠部屋等を 配し、送迎の作法に必要な空間を用意し、Bゾーンは主屋の御 広間に面し、Cゾーンは主屋の御居間に面し、Dゾーンは小屋、 下雪隠、御道具藏、池を配し、家政向けの空間を用意していた。 またA、B、Cゾーンは表から奥へと順に配され、慗がりのある

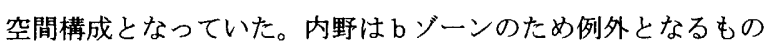
の、赤間・山家は各ゾーンを通過しないとCゾーンにたどり着 けない。

\section{3. 福岡藩御茶屋の内部空間構成}

各御茶屋は区分された各ゾーンに対応するように平面をグル ーピング出来る。グルーピングは主屋の諸室がどのゾーンに面

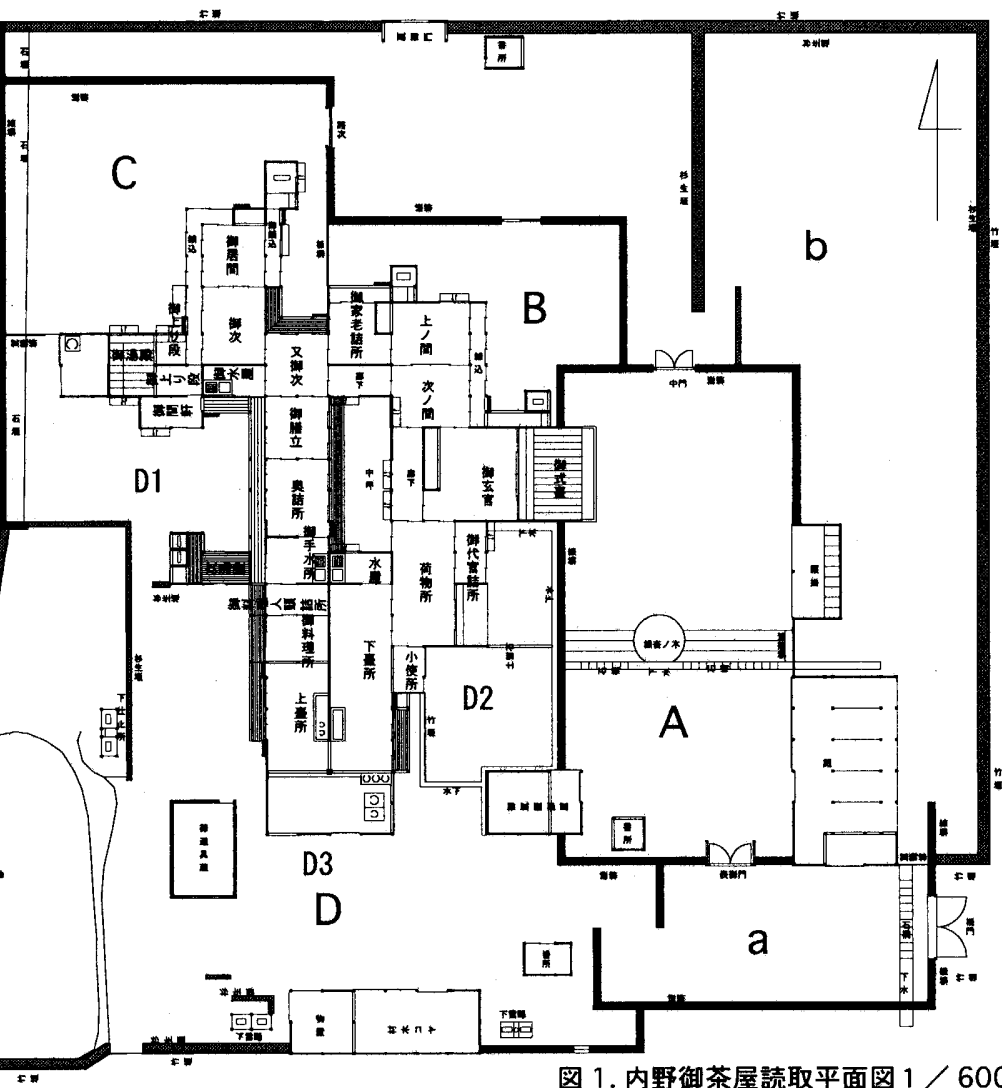

図 1.内野御茶屋読取平面図 $1 / 600$
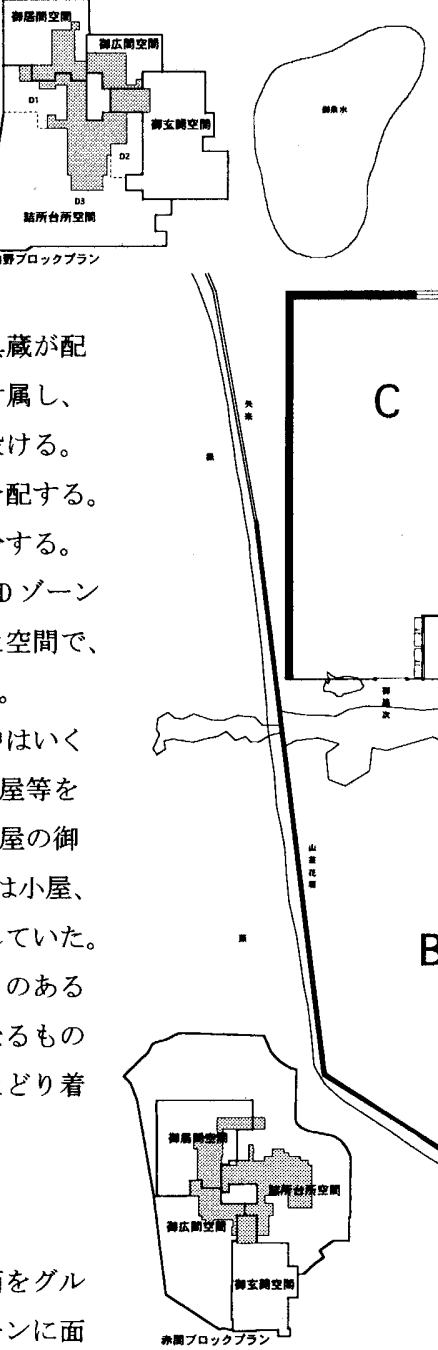

.
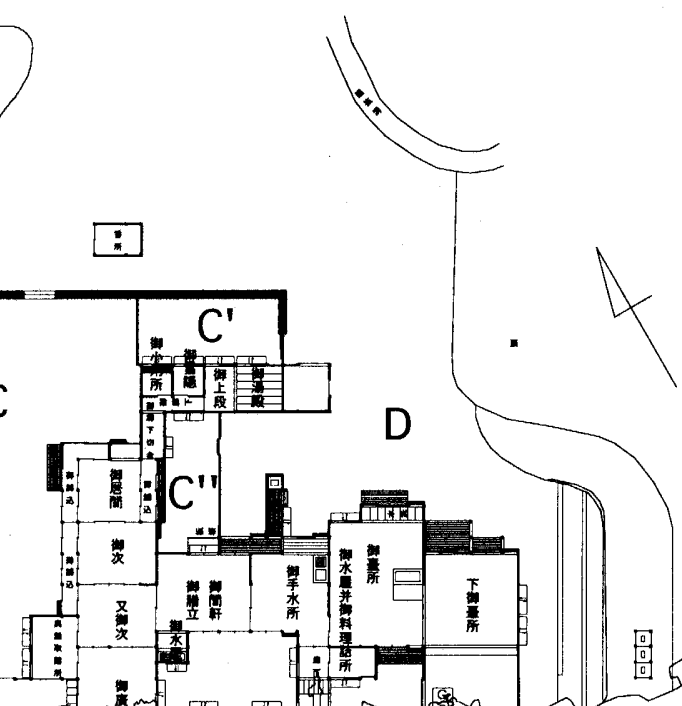

(1)

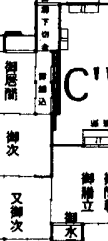

D
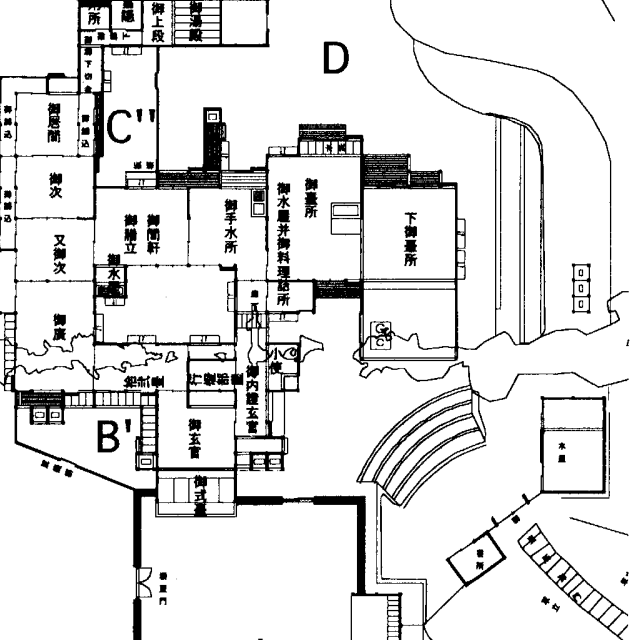

A



図 2. 赤間御茶屋読取平面図 $1 / 600$ 
するかを基本とし、いくつかのゾーンに面する場合や 全く面しない場合は建具や壁の配㯰により決定した。 この結果から得られるグループと外部空間構成で検討 したゾーンを一体として捉えることが、福岡藩御茶屋 の基本空間構成を導き出すと考えられよう。これらは 決して部屋名でグルーピングしているわけではない。 Aゾーンに対応するグループの諸室はともに「御式 薹」「御玄官」で、送迎の機能を担っていたと考えられ、 Aゾーンとこれら諸室を一体とし御玄関空間と呼ぶ。

Bゾーンに対応するグループの諸室はともに「御広 間」「次の間」である。内野は「御家老詰所」も対応 する。赤閒の B' ゾーンは「御廣閒」「12 畳の部屋（室 名不祥)」が対応する。これらは対面とそれを補助す る機能を担っていたと考えられ、これらのゾーンと諸 室を一体として御広間空間と呼ぶ。

Cゾーンに対応するグループの諸室はともに「又御 次」「御次」「御居間」「御上り場」「御湯殿」である。 赤閒と山家は「奥頭取詰所」が、山家は「御閒軒」「御 水屋」が対応する。C’ゾーンに対応するグループの 諸室は赤間が「御小用所」「御雪隠」「御上段」「御湯 殿」で、山家は「御寝所」である。C'”ゾーンに対応 する諸室は「御居間」「御小用所」「御雪隠」「御上段」 である。これらは休息とそれを補助する機能を担って いたと考えられ、これらのゾーンと諸室を一体として 御居間空間と呼ぶ。

Dゾーンに対応するグループの諸室はともに「下臺 所」「御手水所」である。内野と赤間は「御噮立」「御 臺所」「水屋」「小使所」が対応し、赤間と山家は「内 證玄官」が対応し、内野と山家は「御代官詰所」が対 応し、内野は「御料理人頭詰所」「奥詰所」「御料理所」「荷 物所」御間軒」が対応し、赤間は「行灯部屋」が対応し、


山家は「表惣詰」「次䎂詰」が対応する。山家のD’ゾーンに対応する 諸室は「御膳立」「上臺所」である。これらは管理と家政機能を担つ ていたと考えられ、これらのゾーンと諸室を一体として詰所台所空閒 と呼ぶ。さらに内野はD1ゾーンと「御水屋」「御間軒」「御膳立」「奥 詰所」「御手水所」「次湯殿」、D2 ゾーンと「御代官詰所」「荷物所」「小 使所小D3 ゾーンと「御料理人頭詰所」御料理所」水屋」「上臺所」「下 臺所」をそれぞれ詰所台所空間 $1,2,3$ と呼ぶ。

以上の結果を基に空間構成を整理し表にした（表 1)。

各御茶屋で部屋名が相違するもので、平面上の位置および乎び名か ら類推される用途が明らかに同じと考えられるものは同じ部屋と見做 した注24)。各御茶屋に見える同じ用途の部屋で違うグループに分けら れたものに御家老詰所・御間軒・御水屋がある。御家老詰所は御広間、 又御次の間の部屋で「山家文久図」からは御広間での御出会時はここ に御家老が控え、藩主が御居間へ移動後は奥頭取がここに控えたこと が知られ、どちらの空間にも属する用途を有していたことが知られる。 この結果、相違が出たと考えられよう。御間軒、御水屋もこのような 二重性を持っていたのであろう。

よって福岡藩御茶屋の空間構成は御玄関空間、御広間空間、御居間 空間、詰所台所空間の 4 つに整理され、それから導かれる機能も送迎

表 1 御茶屋区分表

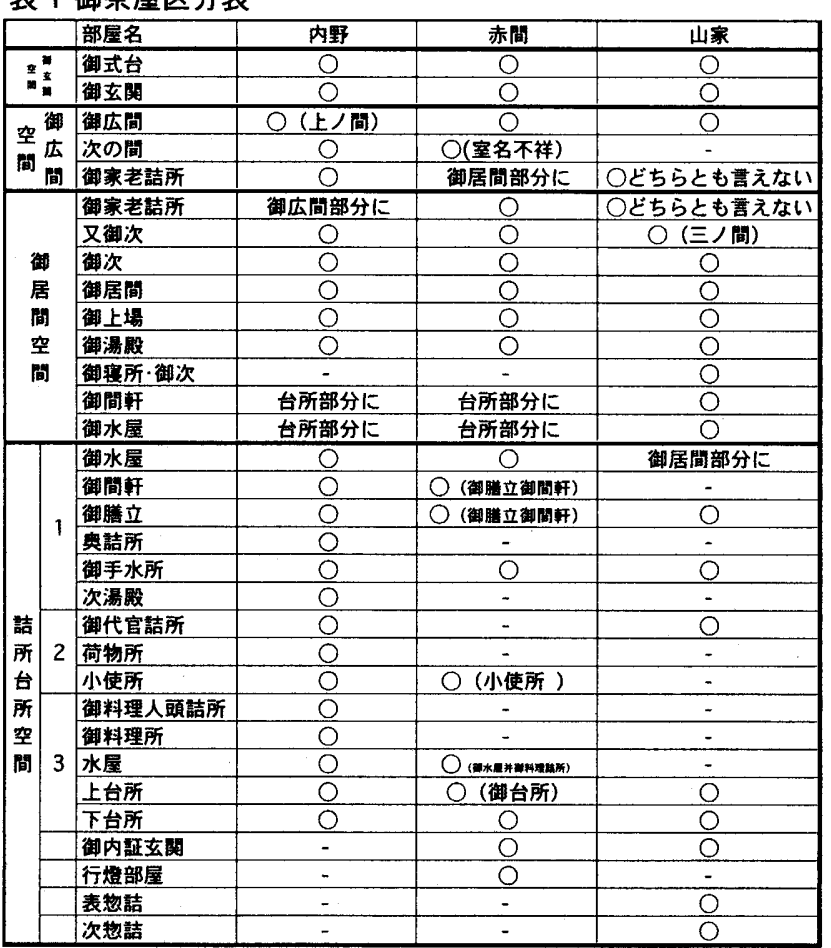


の場、対面の場、休泊の場、管理・家政の場と 4 つにわけられ、空間 と機能が対応を見せる。

また表から共通して見える諸室を拾うと、御式台・御玄関・御広閒・

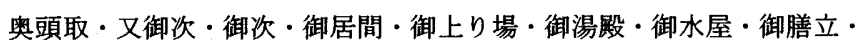
御手水所・上台所・下台所がある。これらが基本的な諸室と考えられ、 平面形式に福岡藩御茶屋の共通性の存在が知られる。

相違する諸室は、内野が御料理人頭詰所、奥詰所、御料理所、次湯 殿を設けること、赤間が御玄関と御広間の閒の次の閒を広く取り、行 灯部屋を設けること、山家が御寝所、御次 (御寝所の)、表惣詰、次 惣詰を設けることで、内野は詰所台所空間を、山家は御居間空間と詰 所台所空間を、赤間は御広間空間を充実させていたことが把握される。 よって各御茶屋が特徴を備えていることが窥える。

\section{4. 内野・赤間・山家御茶屋の意匠構成}

4 つに区分された空間はどの様な意匠を呈していたのであろう。 内野・赤間の絵図に見える主屋と付属屋の床仕上、天井仕上、壁仕上、 建具と練塀の意匠の文言および使用場所を以下に挙げ、解釈の必要な ものは括弧に記した。

建具は「戸」(板戸) 注25〉「襖」「杉戸」「腰障子」「明障子」「空障子」「ま いら戸」「雨戸」「無双レンシ」(無双連子)「張レンシ」(張連子)「引上戸」 「掛戸」「大戸」があり、襖戸、杉戸、板戸が内部間仕切りに、その他 が外部との境に配される。床仕上は「七島」「七島耳絶」（縁のない七 島表曽)「石見」「拭板」「スノコ」「竹エン」があり、竹仕上が縁に用 いられる。壁仕上は「白土」(白漆喰壁）錆土」(錆土壁)「中塗込」(中 塗壁）がある。天井仕上は「板天井」(竿縁天井）注26)「板天井煤色付」 （煤色付竿縁天井）「天井なし」がある。家具は「イロリ」「ナガシ」「䆭」 「戸袋」がある。屋根仕上は「茅」注27)「欠略瓦」(栈瓦) 注28）「目板瓦」 がある。塀・垣には「練塀」「駕籠塀」「板塀」「竹垣」「杉生垣」「山 茶花垣」「矢来」がある。

また、絵図から意匠を詳細に把握できない山家は『江戸参府紀行』 注 29）から内部意匠が知られ、御居間・二ノ間の間は六枚の襖、天井板 は杉、壁は貝殻石灰で、御居間を桃色、二ノ間を黄土色とし、襖意匠 は御居間側を金色、二ノ閒側を花模様、襖縁は黒漆とし、御居間は一 フィート高くしていたと伝え、御居間が上段であったことが知られる。

これら文言から把握される意匠がどの部分に使用されていたのかを 表にまとめた（表 2）注30)。この表からは、内野・赤間・山家の意匠 構成がほぼ一致を見ることが知られ、その中でも詳細を知れるのが内 野であることが把握されよう。表には例外が見られるものの、内外部 の意匠を以下のように特徴付けることができる。

御玄関空間は外部に白壁の栈瓦莫き練塀を巡らし、内部は竿縁天井、 白漆喰壁、襖戸で特徽付けられ書院造の意匠を呈する。御広閒空閒は 外部に中塗壁の目板瓦葺き練塀を巡らし、内部は竿縁天井、白漆喰壁、 襖戸で特徴付けられやや砕けた書院造の意匠を呈する。御居間空間は 外部に中塗壁の目板瓦薑き練塀を巡らし、内部を錆土壁と煤色付竿縁 天井で特徴付けられ数寄屋風注 ${ }^{31)}$ の意匠を呈する。詰所台所空間は外 部に杉生垣・竹垣を巡らし、内部は板戸、中塗壁、縁なし異または拭 板で特徴付けられ民家風注32）の意匠を呈する。

さらに、内野の詰所台所空間 1 は外部に杉生垣を巡らし、内部は竿 縁天井、白漆喰壁、縁のある七島畳、板戸で特徵付けられ、詰所台所 空間 2.3 は外部に杉生垣、竹垣、栈瓦中塗仕上の練塀を巡らし、内部

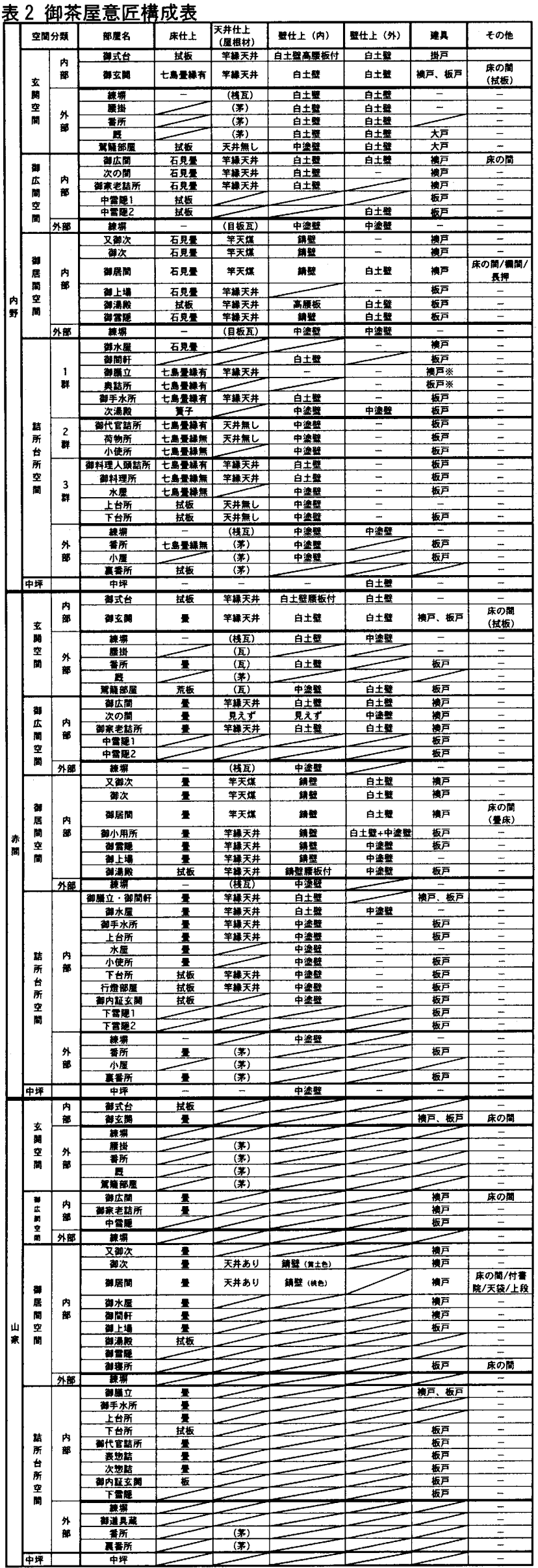

/は文字情報なしを表す。一はそれ自体が存在しないことを表す。 
は天井なし、中塗壁、縁のない七島盢、板戸で特徴付けられる。 床の間は御玄関、御広間、御居間に 3 御茶屋とも備え、御玄関の床 の間は 1 間半 -2 間と幅広くする。山家は御寝所にも床の間を設ける。 床の間が御玄関空間・御広間空間・御居間空間の 3 力所に存在するこ とから、それぞれの空閒で異なる使い方があったと考えられる。

3 御茶屋で相違する意匠は御玄関空間付属屋を赤間が瓦葺きとする が他は茅幕きとすること、上台所の床仕上を内野は拭板、他は冨とす ること、上台所の天井仕上を内野は天井なし、赤間は竿縁天井とする こと、中坪の壁仕上を内野は白漆喰壁、赤間は中塗壁とすること、 座敷意匠を山家は御居間に付書院・天袋を設け、上段とし、御居間意 匠を充実させていたことが举げられる。

以上、御玄関空間は書院造を基本とし、幅広の床の間を備えた格式 高い意匠を呈し、送迎の場が用意され、御広間空間も畫院造を基本と するが、練塀を中塗壁目板瓦とやや砕けた意匠を呈した対面の場が用 意され、御居間空間は数寄屋風意匠を基本とした筧いだ意匠を呈し、 休泊の場が用意され、詰所台所空間は民家風意匠を基本とする質実な 意匠を呈した詰所・家政の場が用意されていた。よって空間と機能と 意匠とが明快に区分されると言えよう。相違点は少なく、内野の上台 所が質素であることと、山家の御居間意匠の充実が挙げられる。

\section{小結}

本稿では、福岡藩御茶屋の建築的特徵を明らかにするため、内野・ 赤間・山家御茶屋の平面絵図を基に読取平面図を作成し、それぞれの 共通点と相違点および外部と内部の関係に着目し、考察を行った。

外部空間を考察することで、3 御茶屋の配置構成が合致し、敷地周 囲に囲繞装置を設け、さらに敷地外周を薮・下代屋敷・水路で囲うな ど閉鎖的な構えを呈し敷地中央に主屋を構え、主屋中央に中庭を取り、 敷地の中は塀や垣により大きく4つのゾーンに区分され、ヒエラルキッ シュな空間構成とすることが明らかとなった。

また、外部空間の結果から内部空間を考察することで、御玄関空間・ 御広間空間・御居間空間・詰所台所空間の $4 つ$ つ分が導き出され、 内部と外部が一体的に捉えうることを指摘した。

さらに 3 つの平面を比較することで、平面形式に共通性が見いだせ るとともに、内野が御料理所等を設け詰所台所空間を充実させ、赤間 が次の間を広く取り御広間空間を充実させ、山家が御寝所、惣詰等を 設け御居間空間、詰所台所空間を充実させ、場所の違いにより個性を 持つことも明らかとなった。

最後に意匠構成を考察することで、御玄関空間が畵院造を基本とし た格式高い意匠を呈し、御広間空間も書院造を基本とするが、やや砕 けた意匠を呈し、御居間空間が数寄屋風意匠を基本とした寛いだ意匠 を呈し、詰所台所空間が民家風意匠を基本とする質実な意匠を呈し、 外部をも含めた空間が 4 つの異なるコンセプトで成立していることが 明らかとなった。

先行研究の萩藩・埌内藩と平面構成を比較すると、萩藩・生内藩と 福岡藩は、荻藩・生内藩における番所部分は御玄関空間と詰所台所空 間に、御座間部分は御居間空間に、台所部分は詰所台所空間に対応す る諸室がみられ共通性が見いだせる。また、福岡藩では御式台、御玄 関を用意するのに対し、萩藩・生内藩では必ずしもこの両方を用意せ ず、福岡藩では御広間を必ず設けるが、萩藩ではほとんど設けず、設 けた場合も福岡藩と空間構成が全く違い、福岡藩御茶屋は対面の場に
相応しい表向きの空間の御玄関空間、御広間空間が充実する点に、藩 主の宿舎として機能した福岡藩御茶屋の特色が見出せる。萩藩にこれ らが見当たらないことは御茶屋敷地に勘場が設けられていたことに関 係すると考えているが、これらの問題は次稿以降の課題としたい。

注 注 1)川上貢「茶屋の意味について」(『日本建筑史論考』中央公㖮美術版、1998) 注 2）丸儿雍成『日本近世交通史の研究』（吉川弘文館、1989）等 注3）中島義一「御殿と御茶屋」(『季刊地域》11、1982) 等 注 4)これらの他に、井出隆正『近世豊前国小倉藩に打引「御条屋」について』(平成 11 年

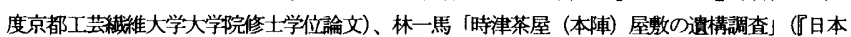
建学学会九州支部研究報告』41、2002）がある。井出氏は小合潘の御菜屋全体を取り上げ、一 つつの御菜屋に関して史料を整理し、御菜屋は多種多様で、細り期は遊興的で小笠原期は交 通的であるとし、御茶屋は座教部之家政所に分けられ、寝所が座䑤と併用されていたとされる。 注 5）川上貢「永原御茶屋の建策」(『日本建策史論考』中央公論美術出版、1998)

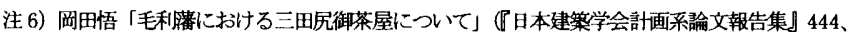
pp127ー137、1993.2) 阙田悟「毛利䊩主国迥り時の休泊に用いられた御茶屋について」『日 本建築学会計画采論文報告集』464、pp181 - 189、1994.10) 等

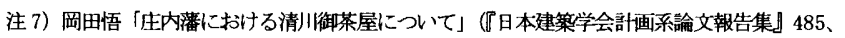
pp173-182、1996.7) 等

注 8)「内野御苯屋絵図」(文化 8 年、安田家久家藏)

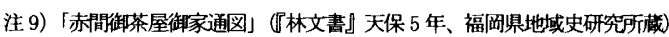

注 10）「御䓇屋々タ御家址数其外口々書留入在役臬役宅坪数共」(文政 5 年、『林文書』福岡県

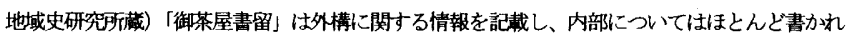
ていない。

注 11）近藤典二「福岡瀋の御茶屋と町萊屋」『西南地域史研究』8、1994) 注 12）太田静六『福剛県の民家とその周辺』(九州大学建案学教宝、1973) 注 13）「山家駅御茶屋絵図」(『三奈木黑田家文畫』京保元年、九州文化史研究所蔵)

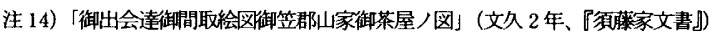
注 15）「山家御莱屋二付奉行出会之節」『三奈木黒田家文書』九州文化史研究可藏藏)

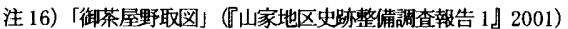

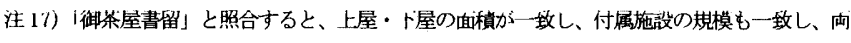
史料准恣性は高い。

注 18）「御䒩屋書留」より屋根材料は上屋を茅蓦き、下屋を瓦草きとすることが知られる。 注 19）赤い点線部分には空、外部に引上戸もしくは撕戸等、夷線部分には襖、戸等の文言が見え、 空、掃き出しの建具を表していることが容易に把撞できる。

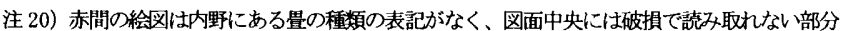

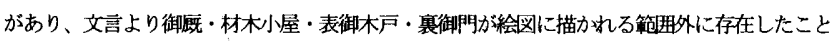
が把握される。

注 21）「内野御茶屋絵龱」「赤間御茶屋御家通图」との比定から考えられる。



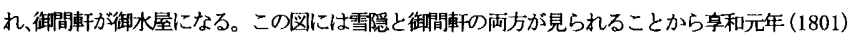
以降文久二年 (1862) 以前の状况を描くと推察される。

注 23）山家に関しては「山家亲和図」を基本とし、外構の一部は作成できていない。 注 24）以下、表 1 に整理した部屋名を使用する。

注25)「戸は锚、障子、舞良戸以外であることから板戸と解粎できる。

注 26）内野御䒩屋俚明治三年に発止されたが、明治五年に至って西光寺の庫赛として御荼屋の

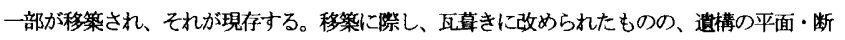

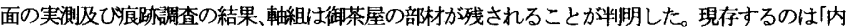

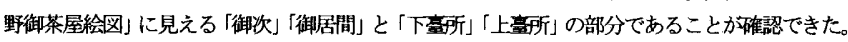

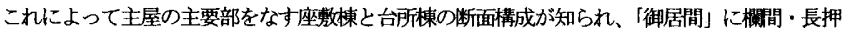
が存在したこと、上段の間でないことが確認され、「板天井」が笋剥天井を表すことも知られた。 注 27）「御茶屋畫留」による。

注28）簡略瓦の意として栈瓦と解釈する。

注 29）斉藤誩訳『江戸参府紀行』(東洋文連、1967)

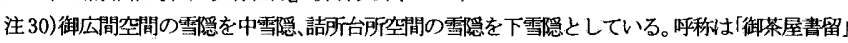
による。

注 31）数寄屋風忶平井聖『日本住宅の歴史』(日本放送出版協会、1974）p168に「数奇屋の影 響を受计た書院を、数奇屋風の晝院と呼ぶことにする。また、その特徵をなす意匠を数奇屋風 の意匠と名付ける。と定義され、これを援用する。

注 32）民家風は民家の畫院座敖を除いた部分に特儌的にみられる意匠を指す。

(2005年 9 月 10 日原稿受理, 2006年 1 月 16 日採用決定) 